\title{
Tree Species Preferred for Wood Fuel in Brick Making in Morogoro Municipality, Tanzania
}

\author{
Kija Steven Magembe ${ }^{1^{*}}$, Fortunatus B. S. Makonda ${ }^{2}$ \\ ${ }^{1}$ Lecturer, Department of Mass Education, Institute of Adult Education, P. O. Box 20679, Dar es Salaam, TANZANIA \\ ${ }^{2}$ Associate Professor, Department of Wood Utilization, Sokoine University of Agriculture, P. O. Box 3014, Morogoro, TANZANIA \\ *Email for Correspondence: stevenkmagembe2001@gmail.com
}

\begin{abstract}
This study aimed at identifying the tree species commonly used in brick making in Morogoro Municipality, Tanzania and proposing means for generation of modified energy sources that would cover the full value of forest resource production and consumption. The research approach was twofolds using; Participatory Rural Appraisal (PRA) and quantitative measurements. Results revealed that almost all brick makers in the area used fuelwood as the major energy sources. Nine (9) tree species were used in brick making, namely; Mkarati (Burkea africana), Mlama (Combretum molle), Mbiriti (Senna siamea), Muarobaini (Azadirachta indica) and Mwembe (Mangifera indica). Others were Mkaratusi (Eucalyptus spp), Mchongoma (Pithecellobium dulce) Mjohoro (Senna spectabilis) and Mkrisimasi (Delonix regia). Of these, Mkarati, Mwembe, Mlama and Mbiriti were mostly preferred, though other species were also used insignificantly. Increasing scarcity of some of other tree species meant that deforestation from the nearby forests was a common problem. To reduce deforestation in the area, use of alternative energy sources in brick making such as rice husks and bagasse are recommended. Other recommendations are the establishment of woodlots, practicing agro-forestry systems and intensive afforestation and reforestation programmes for more sustainable fuelwood use.
\end{abstract}

Key words: Tree, species, brick making, Morogoro, Tanzania

\section{INTRODUCTION}

Wood fuel is the world's fourth largest energy source providing about $13 \%$ of the total energy consumption. The other energy sources are electricity, 36\%, petroleum 34\% and coal 26\% (EIA, 2004; EIA, 2007). In developing countries, it is the most important source of energy reaching 33\% of the total energy use. Nearly 2 billion people in developing countries depend on traditional fuels, which are wood, dung and crop residues (Anderson, 1996; Alam, 2006). Most of the wood fuel comes from forests, mainly wood and charcoal. Forestry is a source of livelihood for many farmers and rural households in developing countries (Ayotebi, 2000; Abebaw, 2007). Many exotic trees have introduced to Africa in the attempt to find quickly growing alternatives to native species (Evans, 1982). Usually, wood with higher density is better suited as fuelwood because it has high calorific value. In 1995, about 3,350,000 $\mathrm{m}^{3}$ of wood were harvested worldwide, of which $63 \%$ were used for energy production $(\mathrm{FAO}, 2000)$.

In Morogoro Municipality, brick making is mainly practiced on the river banks where it competes with urban agricultural activities similarly to the findings reported in Sudan (Ishtiag et al., 2012). To integrate brick making into the diverse land use pattern of urban areas remains a challenge to the municipality and to urban planners.

Though the government has drawn the attention of insisting people to conserve their environment such as planting trees in their areas for fuelwood and other needs, still people are continuing cutting trees from the nearby forests for many purposes. Indiscriminate use of many indigenous trees from forested areas has a significant impact to the 
environment. Such uses may include charcoal making, brick burning, drying of tobacco, smoking fish and use of large amounts of indigenous trees as wood fuel in public service institutions such as restaurants, training institutions, hospitals and prisons (Kilian and Scharpenberg, 1993).The intention of this research was to identify the tree species commonly used in brick making in Morogoro Municipality, Tanzania and its effect to the nearby forests. Results from this study can be used as a base to monitor forest threats, ecological changes and hence develop forest management strategies, solutions and options for the benefit of people in the area and the nation as a whole. This study was carried out in Morogoro Municipality, Tanzania, with the objective of determining tree species preferred for wood fuel, sources of fuelwood and consumption patterns.

\section{Material AND Methods}

\section{Description of the study area}

Morogoro Municipality is about 195 kilometers to the west of Dar es Salaam and is situated on the lower slopes of Uluguru Mountains whose peak is about 1,600 feet above sea level. It lies at the crossings of longitudes 37.0 east of the Greenwich Meridian and latitude 4.49 south of Equator. Morogoro Municipality has a total land area of 531 sq. $\mathrm{kms}$. This land coverage constitutes $0.4 \%$ of the total regional area. The major physical features include the famous Uluguru Mountains, which lie in the southeastern part, and Mindu mountains, which lie in the western part. With a human population of about 316,603 the municipality is divided administratively into 19 wards, of which 7 were purposively selected for this study namely Mazimbu, Kihonda, Mwembesongo, Kichangani, Kilakala, Bigwa and Mzinga.

\section{Sampling, data collection and analysis}

The sampling units were large scale brick making centres of in which, all 35 centres $(100 \%)$ in the municipality were sampled. Boyd et al. (1981) recommended a sample size of at least $5 \%$.The primary data were obtained through PRA, using participant observations, structured questionnaires and interviews to the brick makers. The vernacular names of tree species were translated into botanical names using available checklists by Mbuya et al. (1994). Whereas in qualitative analysis the summarized data were coded and used for subsequent statistical analysis employing Statistical Package for Social Science (SPSS), Microsoft Excel program was used for quantitative data. Descriptive statistics were used to summarize the data in frequency tables and percentages.

\section{Results and Discussion}

\section{Tree species commonly used in brick making}

From Table 1, Mkarati (Burkea africana), Muarobaini (Azadirachta indica), Mlama (Combretum molle) and Mbiriti (Senna siamea) were the most desirable firewood according to the ranking by percentage. Local people's preference ranking on heat energy production for the tree species were vital constituent for determination of firewood quality.

Table 1: Tree species commonly used for fuelwood in brick making in Morogoro Municipality ranked in descending order

\begin{tabular}{|l|l|c|c|l|}
\hline $\begin{array}{l}\text { Vernacular } \\
\text { name/common name }\end{array}$ & $\begin{array}{l}\text { Scientific } \\
\text { name/botanical name }\end{array}$ & $\begin{array}{c}\text { Volume } \\
\left(\mathrm{m}^{3}\right)\end{array}$ & $\begin{array}{l}\text { Percentage } \\
\text { volume wise }\end{array}$ & Reasons for species preference \\
\hline Mkarati & Burkea africana Hook. & 4,078 & 47.4 & Does not spit or spark when burning \\
\hline Muarobaini & Azadirachta indica A. Juss & 1,212 & 14.1 & The wood is relatively heavy \\
\hline Mlama & $\begin{array}{l}\text { Combretum molle R.Br. ex } \\
\text { G. Don }\end{array}$ & 933 & 10.8 & Non-toxic smoke and last longer \\
\hline Mbiriti & $\begin{array}{l}\text { Senna siamea (Lam.) } \\
\text { Irwin \& Barneby }\end{array}$ & 932 & 10.8 & Its wood is easy to light \\
\hline Mwembe & Mangifera indica L. & 872 & 10.1 & Produce wood without thorns \\
\hline Mjohoro & $\begin{array}{l}\text { Senna spectabilis (DC.) } \\
\text { H.S. Irwin \& Barneby }\end{array}$ & 373 & 4.3 & Does not crumble \\
\hline Mkaratusi & Eucalyptus spp & 119 & 1.4 & Good burning qualities \\
\hline Mchongoma & $\begin{array}{l}\text { Pithecellobium dulce } \\
\text { (Roxb.) Benth }\end{array}$ & 70 & 0.8 & Easy to light \\
\hline Mkrisimasi & $\begin{array}{l}\text { Delonix regia (Bojer ex } \\
\text { Hook.) Raf. }\end{array}$ & 23 & 0.3 & Its wood produces a lot of heat \\
\hline \multicolumn{2}{|l|}{ Total } & $\mathbf{8 , 6 1 0}$ & $\mathbf{1 0 0 . 0}$ & \\
\hline
\end{tabular}

Source: $\left[{ }^{1}\right]^{*}$ Author's Computation 


\section{Volume contribution of preferred the tree species}

Burkea africana $\left(4,078 \mathrm{~m}^{3}\right)$, Azadirachta indica $\left(1,212 \mathrm{~m}^{3}\right)$ and Mangifera indica $\left(872 \mathrm{~m}^{3}\right)$ together made up $8,027 \mathrm{~m}^{3}$ of the total tree species volume consumed as fuelwood in brick making. The rest of the species (Eucalyptus spp, Senna siamea, Pithecellobium dulce and Delonix regia) contributed $585 \mathrm{~m}^{3}$ of the total volume as shown in Table 1. High volume contribution for the named species (Burkea africana, Azadirachta indica, Combretum molle, Senna spectabilis and Mangifera indica) suggests that they are mostly used as fuelwood in brick making. On the other hand, low volume contribution for the other tree species means that such species are not frequently used as fuelwood in brick making. The reason is due to the relative unavailability of some of the tree species as the case for Senna spectabilis.

Among the preferred species, Senna spectabilis (4.3\%), Eucalyptus spp (1.4\%), Pithecellobium dulce (0.8\%) and Delonix regia $(0.3 \%)$ are the least in terms of percentage by volume as it is shown in Table 1 . Preferred tree species with limited distribution and low percentage in species composition should be considered as rare/endangered species. The observed uncontrolled harvesting of homestead tree species mainly for fuelwood is among the factors that signify the decline of the species in the municipality.

\section{Sources of fuelwood for brick making}

Fuelwood is obtained both from the nearby forests and homestead areas. The common forest sources were: Kiegea (Mkundi area, Morogoro Municipality), Vianzi and Bwawa la Kobe (Lukobe area, Morogoro Municipality), Nyang'wambe and Lukangazi (Mikese area, Morogoro Rural District) and Malaka (Doma-Msongozi area, Mvomero District). Others were; Lubungo, Mindu Hills, Mafulu and Kimambila (Mindu area, Morogoro Municipality), and Lugala (Lugala Hills, Morogoro Municipality). Homestead areas included home gardens, trees from fenced and agricultural lands (Table 2).

Table 2: Sources of fuelwood for brick making in Morogoro Municipality

\begin{tabular}{|c|c|c|c|c|}
\hline Area & Forest name & Location & $\begin{array}{l}\text { Distance from } \\
\text { municipality } \\
\text { centre }(\mathrm{km}) \\
\end{array}$ & Species \\
\hline Homestead & $\begin{array}{l}\text { Home gardens, fenced } \\
\text { trees and agricultural lands }\end{array}$ & $\begin{array}{l}\text { Morogoro } \\
\text { Municipality }\end{array}$ & Variable & $\begin{array}{l}\text { Mangifera indica, Azadirachta indica, } \\
\text { Delonix regia, Pithecellobium dulce, } \\
\text { Senna siamea and Eulycaptus spp. }\end{array}$ \\
\hline Mkundi & Kiegea & $\begin{array}{l}\text { Morogoro } \\
\text { Municipality }\end{array}$ & 25 & Burkea africana, Senna siamea \\
\hline Lukobe & $\begin{array}{l}\text { Vianzi, Nguru ya ndege, } \\
\text { Bwawa la Kobe }\end{array}$ & $\begin{array}{l}\text { Morogoro } \\
\text { Municipality }\end{array}$ & 20 & $\begin{array}{l}\text { Burkea africana, Combretum molle and } \\
\text { Senna spectabilis }\end{array}$ \\
\hline Mikese & $\begin{array}{l}\text { Nyang'wambe and } \\
\text { Lukangazi }\end{array}$ & $\begin{array}{l}\text { Morogoro } \\
\text { Rural District }\end{array}$ & 45 & $\begin{array}{l}\text { Burkea africana, Combretum molle and } \\
\text { Senna spectabilis }\end{array}$ \\
\hline $\begin{array}{l}\text { Doma- } \\
\text { Msongozi }\end{array}$ & Malaka & $\begin{array}{l}\text { Mvomero } \\
\text { District }\end{array}$ & 50 & Burkea africana, Combretum molle \\
\hline Mindu & $\begin{array}{l}\text { Lubungo, Kimambila, } \\
\text { Mafulu, Mindu Hills and } \\
\text { Lugala, }\end{array}$ & $\begin{array}{l}\text { Morogoro } \\
\text { Municipality }\end{array}$ & $20-50$ & Burkea africana, Combretum molle \\
\hline
\end{tabular}

\section{Discussions}

The preferences for some of the tree species indicated in Table 1 conform to the findings reported by Kgathi and Mlotshwa (1997) and other scientific reports done elsewhere. For example, similar results have been reported in Northern Botswana that, Burkea africana and Combretum molle are the most preferred fuelwood species in brick burning and for other purposes. Reasons cited by Kgathi (1984), Arntzen and Veenendaal (1986), for this preference of the mentioned tree species include the fact that they; give reasonably hot fires and give lasting embers, do not smoke or spark excessively, do not have an unpleasant odour or detrimental effects on health and its wood is cut easily.

Furthermore, reports for the preferences of Azadirachta indica in the study area were similar to what was reported elsewhere. Charcoal made from Azadirachta indica wood is of excellent quality and the wood has long been used as firewood. Its oil is burned in lamps (James, 2000). Puri et al. (2004) reported that Azadirachta indica has long been used as fuel in India, and its wood is relatively heavy with specific gravity varying from 0.56 to 0.85 .

The preference for Senna siamea also indicates that the wood is dense and excellent for fuel, although it produces some smoke when burning (Mhagama, 2002). Brick makers also favour Senna siamea and Senna spectabilis because their wood possesses good combustion characteristics and they grow fast (Tabuti, 2012). The preference for Delonix regia conforms to what was reported by Little and Wadsworth (1964) that the species is widely used in South Africa 
for the same purpose. The preference for Pithecellobium dulce is similar to what was reported in India, Africa and Central and South America (Wealth of India, 1969). The same report on fuelwood consumption in India indicated that Combretum molle was mainly used in brick burning as its wood burns slowly, giving intense heat, and is suitable for firewood and production of high-quality charcoal (Bekele-Tesemma et al., 1993). Burkea africana was preferred mostly due to its property of consuming less fuel in the burn and also its intensity in heat production.

The qualitative characteristics of good firewood specified by respondents in this study are in agreement with what has been described for other parts of Africa, such as Malawi (Abbot and Lowore, 1999).They relate to the wood's basic physical properties, basic density and moisture content which are known to determine the energy content of wood (Bhatt and Tomar, 2002). For example, long lasting fires and strong embers are related to high wood density, while ignition times, fire temperatures and smoke production are related to low moisture content. The study revealed that, the use of the most preferred fuel species in brick making and other purposes could be good tool for species selection in forestry programmes (Chettri and Sharma, 2006).

Similar studies have reported the main sources of fuelwood in Tanzania to be natural woodlands, tropical high forests, fuelwood plantations and, to a less extent individual trees on farmland (Kimaryo and Ngereza, 1989). Nomtshongwana (1999) reported that communities living in uplands of Kwa-Zulu Natal Province of South Africa use $0.25 \mathrm{~m}^{3}$ of firewood per household annually, out of which $47 \%$ are obtained from agro-montane forests that are also watershed areas. According to Shackleton (1993), an average of $0.22 \mathrm{~m}^{3}$ of firewood per household is consumed annually in South Africa, out of which $41 \%$ are obtained from home gardens.

In a recent survey in India, it was found that villages located inside or adjoining the forest meet their total fuel requirements from forests. In areas within $10 \mathrm{~km}$ of forest boundaries about $70 \%$ of the fuel used comes from the forest; beyond $10 \mathrm{~km}$, the use of fuelwood from the forests diminishes steadily until at about $15 \mathrm{~km}$ it is almost nil (Mathur, 1975). However, observations in Pwani (Coast) Region, Tanzania have indicated that farmlands trees mainly old cashew nut and mango trees are also used for fuelwood production (IUCN, 2000). Brigham et al. (1996) reported that, 85 to $90 \%$ of firewood entering Harare market, Zimbabwe; $65 \%$ of total wood energy consumed in Tanzania; and $85 \%$ of total household fuelwood energy requirements $\left(84,000,000 \mathrm{~m}^{3}\right.$ per year) in Mozambique, come from clearance of natural forests and woodlands. In Tamilnadu, about $53 \%$ of the total fuelwood consumed was freely collected and came from horticultural residues, Prosopis species, Acacia species and Casuarina equsetifolia, most of which were growing in non-forest lands. About 20.5\% of fuelwood was sold from the shops, $13.3 \%$ from individually-owned land and only $4.7 \%$ was reported to have originated from forests (Pandey, 2002). In a fuelwood study in North-west Bengal, around $84 \%$ of the rural households were found to collect fuelwood directly from the State forests, $11 \%$ from the home gardens, $1 \%$ from community wastelands and rest from other sources (FAO, 2000). This dependency upon forest for fuelwood creates pressure additive to other causes of forest degradation.

Fuelwood consumption from the nearby forest in brick making is considered as a major source of deforestation. The demands for fuelwood from the forests play a major role in deforestation in two ways. First, trees are cut off without replacement. Moreover urban people cut the remaining trees due to acute shortage of alternative sources of energy. Secondly, the insufficient supply of energy compels people to chop immature trees. Similar results indicated that, commercial exploitation for urban wood fuel markets has impacts in many areas, resulting in failure of supplies to meet the demand and hence this resource is becoming increasingly scarcer and scarcer (Rowe et al., 1992; FAO, 2000). Studies show that availability of fuelwood in urban areas is increasingly becoming difficult whereas the distances from its sources to big cities and towns are increasing (Royal Norwegian Embassy, 2003).

Besides agriculture, fuelwood harvesting is a major source of local forest and woodland degradation in parts of SubSaharan Africa (De Montalembert and Clement, 1983). WRI (2001) reported that about $130000 \mathrm{~km}^{2}$ of tropical forests are cleared every year to meet fuelwood demand, and it is feared that between 4 to $8 \%$ of all forest species are lost in this way.

Particular attention is needed to be paid as to their regeneration and protection. Species like Burkea africana and Combretum molle need to be given special attention for preservation because it is nowadays not easily available from the nearby forests in the municipality. Strengthening agroforestry systems in the study area together with woodlots establishments can, therefore minimize the pressure of extracting fuelwood from the nearby forests and homestead areas.

\section{Acknowledgments}

The authors express sincere thanks to all who helped execution of the study especially the staff members of the Department of Wood Utilization and Development Studies Institute, Sokoine University of Agriculture, Morogoro Tanzania. 


\section{REFERENCES}

A Wealth of India (1969). Raw materials: Pithecellobium dulce Benth Vol. VIII. Council of Scientific and Industrial Research, New Delhi, India. 142pp.

Abbot, P. \& Lowore, J. D. (1999). Characteristics and management potential of some indigeneous firewood species in Malawi. Forest Ecology and Management 119:111-121.

Abebaw, D. A. (2007). Household determinants of fuelwood choice in urban Ethiopia: A case study of Jimma town. Journal of Development Areas 41(1):117-126.

Alam, S. A. (2006). Use of biomass fuels in the brick- making industries of Sudan: implications for deforestation and greenhouse gas emission. Master's thesis Department of Forest Ecology, Viikki Tropical Resources Institute (VITRI), University of Helsinki, Finland. 87pp.

Anderson, D. (1996). Energy and the Environment: Technical and Economic Possibilities Finance and Development. Journal of environmental science 52(3):127-132.

Arntzen, J. W. and Veenendal, E. M. (1986). A profile of Environment and Development in Botswana. NIR University of Botswana, Gaborone. 172pp.

Ayotebi, O. (2000). Overview of environmental problems in Nigeria.National Centre for Economic Management and Administration (NCEMA). Paper presented at the conference on Environment and Sustainable Development: Ibadan, 17-18 August, 2000.

Bekele-Tesemma, A., Birnie, A. \& Tengnas, B. (1993). Useful trees and shrubs for Ethiopia. Regional Soil Conservation Unit (RSCU), Swedish International Development Authority (SIDA). Retrieved from http://www. world.agroforestry centre.org/sea/products/AFDbases/ asp/GlosB. asp.htm.

Bhatt, B. P. and Tomar, J. M. S. (2002). Firewood Properties of some Indian mountain tree and Shrub Species. Biomass and Bioenergy 23:257-260.

Boyd, H .K. R., Westfall, E. \& Stasch, S. F. (1981). Marketing Research, Texts and Cases. Richard, D. Publisher, Illinois, USA. 738pp.

Brigham, T. E., Chihongo, A. W. \& Chidumayo, E. N. (1996). Local, National and International Trade in Miombo Product. In: The Miombo in Transition: Woodlands and welfare in Africa (Edited by Campbell, B.) CIFOR, Bogor, Indonesia. pp-137-174.

Chettri, N. \& Sharma, E. (2006). Assessment of natural resources use patterns: A case study along a trekking corridor of Sikkim Himalaya. Resources Energy Development 3: 21-34.

De Montalembert, M. R. \& Clement, J. (1983). Fuelwood Supplies in the Developing Countries.FAO Forestry Paper No. 42, Rome, Italy. 42pp.

EIA (Energy Information Administration) (2004).World Energy and Economic Outlook: Consumption by Fuel Types, 1970-2020 Projections: EIA, System for the Analysis of Global Energy Markets. Retrieved from http://www.eia. doe.gov/iea. projection. htm.

EIA (Energy Information Administration) (2007). Annual Energy Review. U.S. Department of Energy: Washington, DC. Retrieved from http:/ /www.eia.doe.gov/emeu/aer.pdf.

Evans, J. (1982).Plantation Forestry in the Tropics. Clarendon Press, Oxford, UK.403pp.

FAO (2000). Forest Energy Forum - Newsletter. Retrieved from www.fao.org/3/a-x9192e/x9192e08.htm.

Ishtiag, A., Sahar, B. A., Kamal, E., Detlev, M. \& Andreas, B. (2012). Effects of red brick production on land use, household income, and green gas emissions in Khartoum, Sudan. Journal of Agricultural and Rural Development in the Tropics and Sub-tropics.

IUCN (2000). Fuelwood and Charcoal Uses with Possible Alternative Energy Sources in Ikwiriri and Mbunjumvuleni village-Rufiji District, Tanzania. Retrieved from www.costalforests.tfcg.org /pubs/ REMP\% 2004\%20Techno.htm.

James, E. H. (2000). ABCP Tree List for Environmental Nurseries. Retrieved from www.blackwoodconservation.org/ abcp tree list. htm.

Kgathi, D. L \& Mlotshwa, C.V. (1997). Fuelwood Procurement, Consumption and Substitution in Selected Areas of Botswana. Implications for theory and policy. Retrieved https://inis.iaea.org/search/searchsinglerecord.aspx?recordsFor=SingleRecord\&RN=29066834\# .

Kgathi, D.L. (1984). Aspects of firewood trade between rural Kweneng and urban Gaborone Botswana: a socio-economic Perspective, N. I. R. Gaborone, Working Paper No. 46, 51pp.

Kilian, T. \& Scharpenberg, R. (1993). Potential Use of Coconut Palm Wood in Tanzania, Dar es Salaam, Tanzania. 304pp.

Kimaryo, B.T and Ngereza,K.J. (1989). Charcoal production in Tanzania using improved earth kilns.IDRC Manuscript Report.27pp.

Little, E. L, \& Wadsworth, F. H. (1964). Common trees of Puerto Rico and the Virgin Islands. Agricultural Handbook. No. 249. US Department of Agriculture. Washington DC. Retrieved from http://www.amazon.com/common-trees-puerto-virgin-isla.

Mathur, R. S. (1975).Tropical Agriculture: The Transformation of Tropical Environments by Agriculture. Longman, London. 27pp.

Mbuya, L. P., Msanga, P., Ruffo, C. K., Brirnie, A. \& Tengnas, B. (1994). Useful trees and shrubs for Tanzania: Identifying propagation and management for agricultural and pastoral communities. Regional Soil Conservation Unit (RSCU), Nairobi, Kenya. 542pp.

Mhagama, M. (2002). Urban Forestry and its Role in Mitigating Carbon Emissions: The case of Morogoro Municipality, Tanzania. Special Project for an award of degree in BSc. (Forestry) at the Sokoine University of Agriculture, Morogoro, Tanzania. 488pp.

Pandey, D. (2002).Fuelwood Studies in India. Myth and Reality. Retrieved from http://www.cifor.org/library/1103/fuelwoodstudies-in-india-myth-and-reality/. 
Puri, S., Singh, S. and Bhushan, B. (2004). Evaluation of fuelwood quality of indigenous and exotic tree species of India's Semi-arid region. Journal of Agroforestry Systems 26(2):123-130.

Rowe, R., Sharma, N. P. \& Browder, J. 1992. Deforestation: problems causes and concerns. In: "Managing the World's Forests: looking for balance between conservation and development". (Edited by Sharma, N. P.), Kendall/Hunt Publishing Company, Iowa. pp. 33-46.

Royal Norwegian Embassy (2003).Environmental Project Scores Double. Retrieved from http://www.norway. go.tz/News/Environmental+Project+Ruvu+North.htm.

Shackleton C.M (1993). Fuelwood harvesting and sustainable utilization in a communal grazing land and protected area of the eastern Transvaal lowveld. Biological Conservation 63:247-254.

Tabuti, R. S. (2012). Important Woody Plant Species, their Management and Conservation Status in Balawoli Sub-County, Uganda. Ethnobotany Research and Applications 10:269-286

WRI (2001). Earth Trends: Forests and Grasslands-Mozambique. Retrieved from http://www.earth trends.wri.org/pdf_PDF.

-- 0 -- 